\title{
PHYSICOCHEMICAL PRINCIPLES OF PHARMACY
}

\author{
A. T. FLORENCE \\ The School of Pharmacy \\ University of London \\ and \\ D. ATTWOOD \\ School of Pharmacy and Pharmaceutical Sciences \\ University of Manchester
}

THIRD EDITION

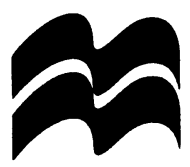




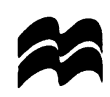

(C) A. T. Florence and D. Attwood 1981, 1988, 1998

All rights reserved. No reproduction, copy or transmission of this publication may be made without written permission.

No paragraph of this publication may be reproduced, copied or transmitted save with written permission or in accordance with the provisions of the Copyright, Designs and Patents Act 1988, or under the terms of any licence permitting limited copying issued by the Copyright Licensing Agency, 90 Tottenham Court Road, London W1P 9HE.

Any person who does any unauthorised act in relation to this publication may be liable to criminal prosecution and civil claims for damages.

The authors have asserted their rights to be identified as the authors of this work in accordance with the Copyright, Designs and Patents Act 1988.

First published 1981 by MACMILLAN PRESS LTD

Houndmills, Basingstoke, Hampshire RG21 6XS

and London

Companies and representatives

throughout the world

First edition 1981

Second edition 1988

Third edition 1998

ISBN 978-0-333-69081-9

ISBN 978-1-349-14416-7 (eBook)

DOI 10.1007/978-1-349-14416-7

A catalogue record for this book is available

from the British Library.

This book is printed on paper suitable for recycling and made from fully managed and sustained forest sources.

$\begin{array}{llllllllll}10 & 9 & 8 & 7 & 6 & 5 & 4 & 3 & 2 & 1\end{array}$

$\begin{array}{llllllllll}07 & 06 & 05 & 04 & 03 & 02 & 01 & 00 & 99 & 98\end{array}$

Typeset in Great Britain by Aarontype Limited

Easton, Bristol 


\section{Contents}

Preface

Acknowledgements

$x$

$x i$

Introduction $\quad 1$

1 Properties of the Solid State 5

1.1 Crystal structure 5

$\begin{array}{ll}1.2 \text { Crystal form } & 8\end{array}$

1.2.1 Crystallisation and factors affecting crystal form ${ }^{2} \quad 9$

$\begin{array}{lll}1.3 & \text { Polymorphism } & 11\end{array}$

$\begin{array}{ll}\text { 1.3.1 Pharmaceutical implications of polymorphism } & 14\end{array}$

$\begin{array}{lll}1.4 & \text { Crystal hydrates } & 18\end{array}$

1.4.1 Pharmaceutical consequences of solvate formation 18

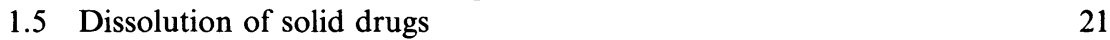

1.6 Biopharmaceutical importance of particle size 22

$\begin{array}{lll}1.7 & \text { Wetting of powders } & 26\end{array}$

$\begin{array}{ll}\text { 1.7.1 Contact angle and wettability of solid surfaces } & 27\end{array}$

$\begin{array}{ll}\text { 1.7.2 Wettability of powders } & 28\end{array}$

$\begin{array}{lll}1.8 & \text { Solid dispersions } & 29\end{array}$

$\begin{array}{lll}\text { 1.8.1 Eutectics and drug identification } & 32\end{array}$

$\begin{array}{lll}1.9 & \text { Summary } & 33\end{array}$

2 Gases and Volatile Agents 36

2.1 Pressure units 36

2.2 Ideal and non-ideal gases $\quad 36$

$\begin{array}{lll}2.3 & \text { Vapour pressure } & 38\end{array}$

2.3.1 Vapour pressure and solution composition: Raoult's law 38

2.3.2 Variation of vapour pressure with temperature: Clausius-Clapeyron equation $\quad 41$

2.3.3 Vapour pressure lowering $\quad 44$

2.4 Solubility of gases in liquids $\quad 46$

$\begin{array}{lll}2.4 .1 & \text { Effect of temperature on solubility } & 47\end{array}$

$\begin{array}{lll}2.4 .2 & \text { Effect of pressure on solubility } & 47\end{array}$

2.4.3 The solubility of volatile anaesthetics in oil 49

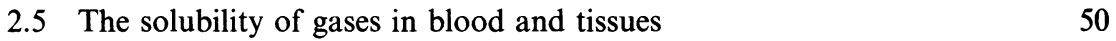

2.5.1 The solubility of oxygen in blood 50

2.5.2 The solubility of anaesthetic gases in blood and tissues 51

2.6 Summary 54

3 Physicochemical Properties of Drugs in Solution 56

3.1 Concentration units $\quad 56$

3.1.1 Weight concentration $\quad 56$

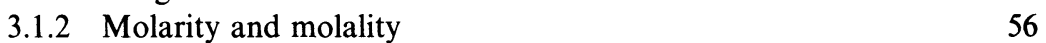

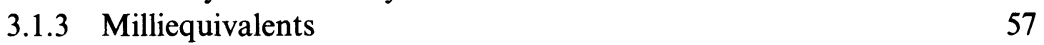

$\begin{array}{ll}\text { 3.1.4 Mole fraction } & 57\end{array}$ 
3.2 Thermodynamics: a brief introduction 58

$\begin{array}{lll}3.2 .1 & \text { Energy } & 58\end{array}$

$\begin{array}{ll}3.2 .2 & \text { Enthalpy } \\ 3.2 .3 & 59\end{array}$

$\begin{array}{llr}3.2 .3 & \text { Entropy } & 59\end{array}$

$\begin{array}{lll}3.2 .4 & \text { Free energy } & 61\end{array}$

$\begin{array}{ll}3.3 & \text { Activity and chemical potential } \\ & 63\end{array}$

$\begin{array}{lll}3.3 .1 & \text { Activity and standard states } & 63\end{array}$

3.3.2 Activity of ionised drugs $\quad 64$

$\begin{array}{lll}\text { 3.3.3 Solvent activity } & 67\end{array}$

$\begin{array}{ll}\text { 3.3.4 Chemical potential } & 69\end{array}$

$\begin{array}{lll}3.4 & \text { Osmotic properties of drug solutions } & 72\end{array}$

$\begin{array}{lll}3.4 .1 & \text { Osmotic pressure } & 72\end{array}$

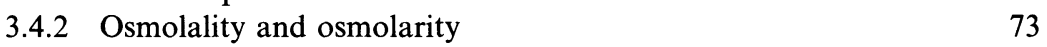

3.4.3 Clinical relevance of osmotic effects $\quad 74$

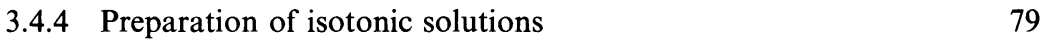

$\begin{array}{lll}3.5 & \text { Ionisation of drugs in solution } & 80\end{array}$

3.5.1 Dissociation of weakly acidic and basic drugs and
their salts

3.5.2 The effect of $\mathrm{pH}$ on the ionisation of weakly acidic or $\begin{array}{ll}\text { basic drugs and their salts } & 82\end{array}$

$\begin{array}{ll}\text { 3.5.3 Ionisation of amphoteric electrolytes } & 88\end{array}$

3.5.4 Ionisation of polyprotic drugs and microdissociation

$\begin{array}{lll}3.5 .5 \quad \mathrm{p} K_{\mathrm{a}} \text { values of proteins } & 90\end{array}$

3.5.6 Calculation of the $\mathrm{pH}$ of drug solutions 90

3.5.7 Preparation of buffer solutions $\quad 93$

3.6 Diffusion of drugs in solution $\quad 96$

$\begin{array}{lll}3.7 & \text { Summary } & 99\end{array}$

4 Drug Stability $\quad 101$

$\begin{array}{lll}4.1 & \text { The chemical decomposition of drugs } & 101\end{array}$

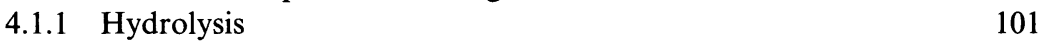

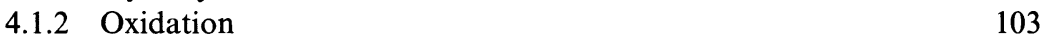

$\begin{array}{lll}4.1 .3 & \text { Isomerisation } & 105\end{array}$

$\begin{array}{ll}\text { 4.1.4 Photochemical decomposition } & 107\end{array}$

$\begin{array}{ll}\text { 4.1.5 Polymerisation } & 108\end{array}$

4.2 Kinetics of chemical decomposition in solution 109

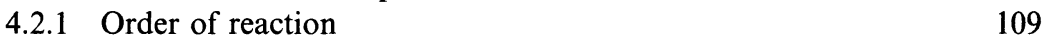

$\begin{array}{ll}4.2 .2 \text { Zero-order reactions } & 110\end{array}$

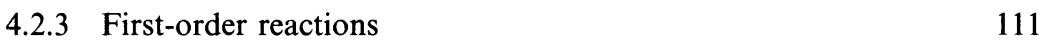

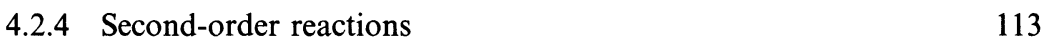

$\begin{array}{lll}4.2 .5 & \text { Third-order reactions } & 114\end{array}$

4.2.6 Determination of the order of reaction 115

$\begin{array}{ll}\text { 4.2.7 Complex reactions } & 115\end{array}$

$\begin{array}{ll}\text { 4.3 Kinetics of chemical decomposition in solid dosage forms } & 120\end{array}$

$\begin{array}{lll}4.4 & \text { Factors influencing drug stability } & 123\end{array}$

$\begin{array}{ll}\text { 4.4.1 Liquid dosage forms } & 123\end{array}$

$\begin{array}{ll}\text { 4.4.2 Semisolid dosage forms } & 135\end{array}$

$\begin{array}{lll}4.4 .3 & \text { Solid dosage forms } & 135\end{array}$ 
$\begin{array}{lll}\text { 4.5 Stability testing and prediction of shelf-life } & 139\end{array}$

$\begin{array}{ll}\text { 4.5.1 Effect of temperature on stability } & 140\end{array}$

$\begin{array}{ll}\text { 4.5.2 Other environmental factors affecting stability } & 147\end{array}$

$\begin{array}{lll}\text { 4.5.3 Protocol for stability testing } & 147\end{array}$

$\begin{array}{lll}4.6 & \text { Summary } & 150\end{array}$

5 The Solubility of Drugs 152

$\begin{array}{lll}5.1 \text { Definitions } & 153\end{array}$

5.1.1 Expressions of solubility 153

$\begin{array}{lll}5.2 & \text { Factors influencing solubility } & 153\end{array}$

$\begin{array}{ll}\text { 5.2.1 Structural features and aqueous solubility } & 155\end{array}$

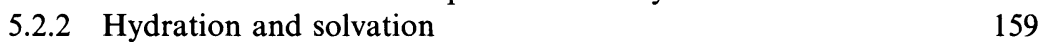

$\begin{array}{lll}\text { 5.2.3 The effect of simple additives on solubility } & 161\end{array}$

5.2.4 The effect of $\mathrm{pH}$ and ionisation on the solubility of ionisable drugs 163

$\begin{array}{ll}\text { 5.3 Measurement of solubility } & 170\end{array}$

$\begin{array}{lll}5.4 & \text { The solubility parameter } & 171\end{array}$

5.4.1 Solubility parameters and biological processes 173

$\begin{array}{lll}5.5 & \text { Solubility in mixed solvents } & 174\end{array}$

$\begin{array}{ll}\text { 5.6 Cyclodextrins as solubilising agents } & 174\end{array}$

$\begin{array}{lll}5.7 & \text { Solubility problems in formulation } & 177\end{array}$

$\begin{array}{lll}\text { 5.7.1 Mixtures of acidic and basic compounds } & 177\end{array}$

$\begin{array}{ll}\text { 5.7.2 Choice of drug salt to optimise solubility } & 179\end{array}$

$\begin{array}{ll}\text { 5.7.3 Drug solubility and biological activity } & 181\end{array}$

$\begin{array}{lll}5.8 & \text { Partitioning } & 183\end{array}$

$\begin{array}{lll}\text { 5.8.1 Theoretical background } & 183\end{array}$

$\begin{array}{ll}\text { 5.8.2 Free energies of transfer } & 185\end{array}$

$\begin{array}{ll}\text { 5.8.3 Octanol as a non-aqueous phase } & 186\end{array}$

5.9 Biological activity and partition coefficient: thermodynamic
activity and Ferguson's principle

$\begin{array}{ll}5.10 \text { Using } \log P & 188\end{array}$

5.10.1 The relationship between lipophilicity and behaviour of tetracyclines 188

$\begin{array}{lll}5.10 .2 & \text { Sorption } & 193\end{array}$

5.10.3 A chromatographic model for the biophase 195

$\begin{array}{ll}5.10 .4 \text { Calculating } \log P \text { from molecular structures } & 195\end{array}$

5.10.5 Drug distribution into human milk 196

$\begin{array}{ll}5.11 \text { Summary } & 197\end{array}$

6 Surfactants 199

6.1 Amphipathic compounds $\quad 199$

6.2 Surface and interfacial properties of surfactants 200

6.2.1 Effects of amphiphiles on surface and interfacial tension 200

$\begin{array}{ll}\text { 6.2.2 Gibbs adsorption equation } & 201\end{array}$

6.2.3 Application of the Gibbs equation to surfactant solutions 204

$\begin{array}{lll}6.2 .4 & \text { Surface activity of drugs } & 206\end{array}$

$\begin{array}{ll}6.2 .5 & \text { Insoluble monolayers } \\ 6.2 .6 & 208\end{array}$

6.2.6 Pharmaceutical applications of surface film studies 213

$\begin{array}{ll}\text { 6.2.7 Adsorption at the solid/liquid interface } & 215\end{array}$ 
$\begin{array}{lll}6.3 & \text { Micellisation } & 224\end{array}$

6.3.1 Water structure and hydrophobic bonding 225

$\begin{array}{ll}\text { 6.3.2 Theories of micelle formation } & 228\end{array}$

$\begin{array}{lll}\text { 6.3.3 Micellar structure } & 229\end{array}$

6.3.4 Factors affecting the critical micelle concentration and micellar size $\quad 230$

6.4 Liquid crystals and surfactant vesicles 233

6.4.1 Liposomes, niosomes and surfactant vesicles 237

$\begin{array}{ll}\text { 6.5 Properties of some commonly used surfactants } & 238\end{array}$

$\begin{array}{ll}\text { 6.5.1 Anionic surfactants } & 238\end{array}$

$\begin{array}{ll}\text { 6.5.2 Cationic surfactants } & 239\end{array}$

$\begin{array}{lll}\text { 6.5.3 Non-ionic surfactants } & 239\end{array}$

$\begin{array}{lll}6.6 & \text { Solubilisation } & 241\end{array}$

6.6.1 Determination of maximum additive concentration 242

$\begin{array}{ll}\text { 6.6.2 Location of the solubilisate } & 243\end{array}$

$\begin{array}{lll}\text { 6.6.3 Factors affecting solubilisation } & 244\end{array}$

6.6.4 Pharmaceutical applications of solubilisation 248

$\begin{array}{lll}6.7 & \text { Summary } & 249\end{array}$

7 Emulsions, Suspensions and Other Dispersions 252

$\begin{array}{lll}7.1 \text { Classification of colloidal systems } & 255\end{array}$

$\begin{array}{lll}7.2 \text { Colloid stability } & 255\end{array}$

7.2.1 Forces of interaction between colloidal particles 256

$\begin{array}{ll}\text { 7.2.2 Repulsion between hydrated surfaces } & 260\end{array}$

$\begin{array}{lll}7.3 & \text { Emulsions } & 264\end{array}$

7.3.1 Stability of o/w and w/o emulsions 264

$\begin{array}{ll}\text { 7.3.2 HLB system } & 266\end{array}$

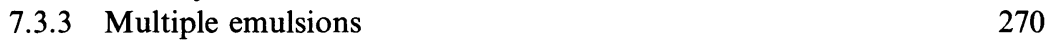

$\begin{array}{lll}7.3 .4 & \text { Microemulsions } & 272\end{array}$

$\begin{array}{lll}\text { 7.3.5 Structured (semisolid) emulsions } & 277\end{array}$

$\begin{array}{lll}\text { 7.3.6 Biopharmaceutical aspects of emulsions } & 278\end{array}$

$\begin{array}{lll}\text { 7.3.7 Preservative availability in emulsified systems } & 279\end{array}$

$\begin{array}{ll}\text { 7.3.8 Mass transport in oil-in-water emulsions } & 280\end{array}$

$\begin{array}{ll}\text { 7.3.9 Intravenous fat emulsions } & 281\end{array}$

7.3.10 The rheology of emulsions $\quad 283$

$\begin{array}{lll}7.4 & \text { Suspensions } & 285\end{array}$

$\begin{array}{lll}\text { 7.4.1 Stability of suspensions } & 286\end{array}$

7.4.2 Aspects of suspension stability 286

$\begin{array}{lll}\text { 7.4.3 Extemporaneous suspensions } & 292\end{array}$

$\begin{array}{lll}\text { 7.4.4 Suspension rheology } & 293\end{array}$

$\begin{array}{lll}\text { 7.4.5 Non-aqueous suspensions } & 294\end{array}$

7.4.6 Adhesion of suspension particles to containers 294

7.5 Applications of colloid stability theory to other systems 298

$\begin{array}{lll}\text { 7.5.1 Cell-cell interactions } & 299\end{array}$

$\begin{array}{ll}\text { 7.5.2 Adsorption of microbial cells to surfaces } & 300\end{array}$

$\begin{array}{ll}\text { 7.5.3 Blood as a colloidal system } & 302\end{array}$

$\begin{array}{lll}7.6 \text { Foams } & 304\end{array}$

$\begin{array}{ll}\text { 7.6.1 Clinical considerations } & 305\end{array}$

$\begin{array}{lll}7.7 & \text { Summary } & 307\end{array}$ 
8 Polymers and Macromolecules $\quad 308$

$\begin{array}{lll}\text { 8.1 Pharmaceutical polymers } & 308\end{array}$

$\begin{array}{lll}\text { 8.1.1 Definitions } & 308\end{array}$

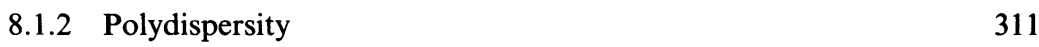

$\begin{array}{lll}\text { 8.1.3 Solubility } & 316\end{array}$

$\begin{array}{lll}8.2 & \text { Water-soluble polymers } & 316\end{array}$

$\begin{array}{lll}\text { 8.3 General properties of polymer solutions } & 317\end{array}$

$\begin{array}{lll}\text { 8.3.1 Viscosity of polymer solutions } & 317\end{array}$

$\begin{array}{ll}\text { 8.3.2 Gelling water-soluble polymers } & 319\end{array}$

$\begin{array}{lll}\text { 8.3.3 Syneresis } & 322\end{array}$

$\begin{array}{lll}\text { 8.3.4 Polymer complexes } & 323\end{array}$

$\begin{array}{ll}\text { 8.3.5 Binding of ions to macromolecules } & 325\end{array}$

8.3.6 Interaction of polymers with solvents including water $\quad 326$

$\begin{array}{ll}\text { 8.3.7 Adsorption of macromolecules } & 328\end{array}$

8.4 Some water-soluble polymers used in pharmacy and medicine 331

8.4.1 Carboxypolymethylene (Carbomer, Carbopol) 332

$\begin{array}{ll}\text { 8.4.2 Cellulose derivatives } & 332\end{array}$

$\begin{array}{ll}\text { 8.4.3 Natural gums and mucilages } & 335\end{array}$

$\begin{array}{lll}\text { 8.4.4 Dextran } & 337\end{array}$

$\begin{array}{ll}\text { 8.4.5 Polyvinylpyrrolidone } & 339\end{array}$

$\begin{array}{lll}\text { 8.4.6 Polyoxyethylene glycols (macrogols) } & 341\end{array}$

$\begin{array}{ll}\text { 8.4.7 Bioadhesivity of water-soluble polymers } & 342\end{array}$

$\begin{array}{lll}\text { 8.4.8 Polymers used as wound dressings } & 343\end{array}$

$\begin{array}{lll}\text { 8.4.9 Polymer crystallinity } & 344\end{array}$

8.5 Water-insoluble polymers and polymer membranes 344

$\begin{array}{lll}\text { 8.5.1 Permeability of polymers } & 345\end{array}$

$\begin{array}{lll}\text { 8.5.2 } & \text { Ion-exchange resins } & 348\end{array}$

$\begin{array}{lll}\text { 8.5.3 Silicone oligomers and polymers } & 352\end{array}$

8.6 Some applications of polymeric systems in drug delivery 354

$\begin{array}{lll}\text { 8.6.1 Film coatings } & 354\end{array}$

$\begin{array}{lll}\text { 8.6.2 Matrices } & 355\end{array}$

$\begin{array}{lll}\text { 8.6.3 Microcapsules and microspheres } & 357\end{array}$

$\begin{array}{ll}\text { 8.6.4 Rate-limiting membranes and devices } & 363\end{array}$

$\begin{array}{ll}\text { 8.6.5 Eroding systems } & 364\end{array}$

8.6.6 Osmotic pumps $\quad 364$

$\begin{array}{lll}8.7 & \text { Summary } & 370\end{array}$

9 Drug Absorption and Routes of Administration 372

$\begin{array}{lll}\text { 9.1 Biological membranes and drug transport } & 373\end{array}$

9.1.1 Permeability and the pH-partition hypothesis 377

9.1.2 Problems in the quantitative application of the
pH-partition hypothesis

9.2 The oral route and oral absorption 386

9.2.1 Drug absorption from the gastrointestinal tract 386

9.2.2 Structure of the gastrointestinal tract 386

$\begin{array}{ll}\text { 9.2.3 Bile salts and fat absorption pathways } & 390\end{array}$

9.2.4 Gastric emptying, motility and volume of contents 390

$\begin{array}{lll}9.3 & \text { Buccal and sublingual absorption } & 392\end{array}$

9.3.1 Mechanisms of absorption 393 
9.4 Intramuscular and subcutaneous injections 395

$\begin{array}{lll}\text { 9.4.1 Vehicles } & 397\end{array}$

$\begin{array}{ll}\text { 9.4.2 Blood flow } & 398\end{array}$

$\begin{array}{lll}9.4 .3 & \text { Formulation effects } & 399\end{array}$

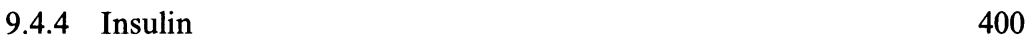

$\begin{array}{lll}9.5 & \text { Transdermal delivery } & 403\end{array}$

9.5.1 Routes of skin penetration 405

9.5.2 Influence of drug 406

9.5.3 Influence of vehicle 408

9.5.4 Dilution of topical steroid preparations 412

9.5.5 Transdermal medication: patches and devices $\quad 412$

9.5.6 Ultrasound and transdermal penetration 415

9.6 Medication of the eye and the eye as a route for systemic

delivery 416

9.6.1 The eye 416

9.6.2 Absorption of drugs applied to the eye 418

$\begin{array}{ll}\text { 9.6.3 Influence of formulation } & 419\end{array}$

9.6.4 Systemic effects from eye drops $\quad 425$

$\begin{array}{lll}9.7 & \text { The ear } & 425\end{array}$

9.8 Absorption from the vagina 426

$\begin{array}{ll}\text { 9.8.1 Delivery systems } & 426\end{array}$

$\begin{array}{lll}9.9 & \text { Inhalation therapy } & 428\end{array}$

9.9.1 Physical factors affecting deposition of aerosols $\quad 429$

9.9.2 Experimental observations $\quad 432$

$\begin{array}{ll}9.10 \text { The nasal route } & 437\end{array}$

9.11 Rectal absorption of drugs 441

9.12 Intrathecal drug administration 446

$\begin{array}{ll}9.13 \text { Summary } & 447\end{array}$

10 Physicochemical Drug Interactions and Incompatibilities 449

$10.1 \mathrm{pH}$ effects in vitro and in vivo $\quad 450$

$\begin{array}{ll}\text { 10.1.1 In vitro } \mathrm{pH} \text { effects } & 450\end{array}$

$\begin{array}{ll}\text { 10.1.2 In vivo } \mathrm{pH} \text { effects } & 452\end{array}$

$\begin{array}{lll}10.2 & \text { Effects of dilution of mixed solvent systems } & 457\end{array}$

$\begin{array}{lll}10.3 & \text { Cation-anion interactions } & 459\end{array}$

$\begin{array}{lll}10.4 & \text { Polyions and drug solutions } & 461\end{array}$

10.5 Chelation and other forms of complexation 463

$\begin{array}{lll}10.6 & \text { Other complexes } & 469\end{array}$

10.6.1 Interaction of drugs with cyclodextrins 470

$\begin{array}{ll}\text { 10.6.2 Ion-exchange interactions } & 471\end{array}$

$\begin{array}{lll}10.7 & \text { Adsorption of drugs } & 472\end{array}$

$\begin{array}{ll}\text { 10.7.1 Protein and peptide adsorption } & 475\end{array}$

$\begin{array}{lll}10.8 & \text { Drug interactions with plastics } & 476\end{array}$

$\begin{array}{lll}10.9 & \text { Protein binding } & 477\end{array}$

10.9.1 Thermodynamics of protein binding 481

$\begin{array}{lll}\text { 10.9.2 } & \text { Lipophilicity and protein binding } & 482\end{array}$

$\begin{array}{lll}\text { 10.9.3 Penetration of specialised sites } & 484\end{array}$

$\begin{array}{ll}10.10 \text { Summary } & 485\end{array}$ 
Appendix: Drug interactions based on physical mechanisms

11 Peptides and Proteins 493

11.1 Structure and solution properties of peptides and proteins 496

11.1.1 Structure of peptides and proteins 496

11.1.2 Hydrophobicity of peptides and proteins 498

$\begin{array}{ll}\text { 11.1.3 Solubility of peptides and proteins } & 501\end{array}$

$\begin{array}{ll}\text { 11.2 The stability of peptides and proteins } & 504\end{array}$

$\begin{array}{lll}\text { 11.2.1 Physical instability } & 504\end{array}$

$\begin{array}{ll}\text { 11.2.2 Formulation and protein stabilisation } & 507\end{array}$

$\begin{array}{ll}\text { 11.2.3 Chemical instability } & 509\end{array}$

11.2.4 Accelerated stability testing of protein formulations $\quad 514$

$\begin{array}{lll}11.3 & \text { Protein formulation and delivery } & 516\end{array}$

$\begin{array}{ll}\text { 11.3.1 Protein and peptide transport } & 516\end{array}$

$\begin{array}{ll}\text { 11.3.2 Lyophilised proteins } & 519\end{array}$

$\begin{array}{ll}\text { 11.3.3 Water adsorption isotherms } & 519\end{array}$

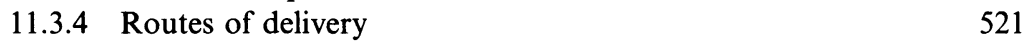

$\begin{array}{lll}11.4 & \text { Two therapeutic proteins } & 522\end{array}$

$\begin{array}{lll}\text { 11.4.1 Insulin } & 522\end{array}$

$\begin{array}{ll}11.4 .2 \text { Calcitonin } & 524\end{array}$

$\begin{array}{lll}11.5 & \text { Summary } & 524\end{array}$

12 Assessment of Dosage Forms In Vitro $\quad 527$

$\begin{array}{lll}\text { 12.1 Dissolution testing of solid dosage forms } & 527\end{array}$

12.1.1 Pharmacopoeial and compendial dissolution tests 528

$\begin{array}{ll}\text { 12.1.2 Flow-through systems } & 530\end{array}$

12.2 In vitro evaluation of suppository formulations 532

12.3 In vitro release from topical products and transdermal systems 533

$\begin{array}{ll}12.4 & \text { Rheological characteristics of products } \\ 12.5 & 537\end{array}$

$\begin{array}{ll}\text { 12.5 Adhesivity of dosage forms } & 540\end{array}$

12.6 Analysis of particle size distribution in aerosols 543

$\begin{array}{ll}12.7 \text { Conclusions } & 549\end{array}$

$\begin{array}{llr}12.8 & \text { Summary } & 549\end{array}$

Index $\quad 551$ 


\section{Preface}

Textbooks are never completed, only abandoned, probably by readers as well as by authors. We have been intent for some time on revising the second edition of this book, published in 1988, but the work of revision took longer than anticipated. Now we are pleased that this new edition has been completed, rewritten and updated but retaining the essential character of the book which has proved successful since the book was first published 17 years ago. We have again used exclusively pharmaceutical examples to illustrate the physical chemistry which is the basis of the book.

Some material has been removed and new material added. There has been a reintroduction of some of the thermodynamics lost from the second edition. A general introduction takes the reader into the subject more gently than before, and there is a new chapter on peptides and proteins as pharmaceuticals. Solutions, the solid state and the gaseous state are discussed (the latter particularly with pressurised aerosols in mind), while ionization of drugs is considered at length as it affects so many properties of drugs in solution, as well as their absorption. Surface chemistry retains its place and the treatment of colloidal systems is enhanced with further discussion of liposomes and other colloidal carriers now used more widely in therapeutics.

The properties of soluble, insoluble and dispersible natural and synthetic polymers elements of many delivery systems - are described. Each route used for delivering medicines is treated by considering the physiology of the route and the conditions of the route that affect the drug and dosage form, with a brief description of the factors affecting the performance of each type of delivery device. Wherever possible calculations and worked examples are included to encourage a better understanding of the equations described. We hope that the book will continue to be useful not only in undergraduate and postgraduate courses in pharmacy but those in the pharmaceutical sciences and related studies too.

A.T. Florence

London

D. Attwood

Manchester

February 1998 


\section{Acknowledgements}

Mrs Maureen Lucas transcribed the text of the second edition of the book on to disk to make the task of revision easier and Mrs Gillian Patterson and Miss Barbara Grant made the many revisions that the text has gone through since work on the third edition was begun, interpreting the additions, deletions and comments. Over the years the book has been in existence, many colleagues have offered both favourable and critical comments that have spurred us on to revise the book. We thank them and encourage them also to write to us with any observations on how the present edition can be further improved.

Alexander T. Florence

London

David Attwood

Manchester 